\title{
Calcium in Cell Walls of Rhizobium trifolii
}

\author{
BY BEVERLEY HUMPHREY AND J. M. VINCENT \\ Microbiology Laboratory, School of Agriculture, University \\ of Sydney, Australia
}

(Received 9 March 1962)

\begin{abstract}
SUMMARY
The cell walls from Rhizobium trifolii, grown under both 'normal' and 'calcium-deprived' conditions, were analysed in an attempt to detect a chemical cause for the apparent weakness or looseness of the walls in calciumdeprived organisms. The organic components typical of Gram-negative cell walls were present in normal and calcium-deprived cells. The latter concentrated most of the small amount of available calcium in the walls, which, however, contained only $60 \%$ of that present in the walls of normal organisms. Magnesium was not able to substitute for calcium as a wall component.
\end{abstract}

\section{INTRODUCTION}

Calcium-deprived cells of Rhizobium trifolii developed an abnormal morphology (Vincent \& Colburn, 1961). They became swollen and much more spherical in form, apparently distorted by a huge vacuole. Although a double-layered wall structure was seen in the calcium-deprived as well as in the calcium-sufficient cells, it appeared to be appreciably weakened in its sectioned appearance. The effect could be one of a loosening of wall structure, and in this paper we have looked for some chemical evidence of this. We have particularly considered the possibility that calcium may be structurally involved.

\section{METHODS}

Organism. Rhizobium trifolii SU 297/31.

Cultural conditions. The organism was grown in a defined medium (Vincent, 1962) having a total concentration of divalent cations of $1 \mathrm{~mm}$. This was made up of either $0.5 \mathrm{~mm}-\mathrm{Ca}^{2+}+0.5 \mathrm{mM}-\mathrm{Mg}^{2+}$ ('normal') or $1 \mathrm{~mm}-\mathrm{Mg}^{2+}$ ('calcium-deprived'). All salts were A.R. grade. Cultures were harvested after $72 \mathrm{hr}$. incubation, with shaking, at $25^{\circ}$.

Preparation of cell walls. Early attempts at a clean cell-wall preparation were frustrated by the presence of up to $50 \%$ poly- $\beta$-hydroxy-butyric acid in the cells (Vincent, Humphrey \& North, 1962). It was found best to remove this polymer first, by lyophilizing the organism and extracting with chloroform for $24 \mathrm{hr}$. at room temperature. Such extracted organisms gave a satisfactory cell-wall preparation by the usual method of Mickle disintegration, trypsin digestion and differential centrifugation.

Identification of wall components. For the identification of sugars, walls were hydrolysed at $100^{\circ}$ for $20 \mathrm{hr}$. in $2 \mathrm{~N}-\mathrm{HCl}$. Chromatography was in butanol acetic acid: water, $6+1+2$ descending, and the papers were developed by $p$-anisidine-HCl.

For the identification of amino acids and amino sugars, walls were hydrolysed 
for $20 \mathrm{hr}$. at $100^{\circ}$ in $6 \mathrm{~N}-\mathrm{HCl}$. Chromatograms were developed with ninhydrin after two-dimensional chromatography in pyridine + water $(4+1)$ and butanol + acetic acid + water $(3+1+1)$.

Calcium and magnesium analyses. These were carried out by the method of atomic absorption spectrophotometry. Five mg. whole cells or cell walls were ashed overnight at $450^{\circ}$ in an electric muffle furnace in covered platinum crucibles. Two ml. of $3 \mathrm{~N}-\mathrm{HNO}_{3}$ were added to the residue and evaporated to dryness on a water bath. The crucibles were again placed in the muffle furnace overnight, after which no visible ash remained. The residue was taken up in $0 \cdot 1 \mathrm{ml} .6 \mathrm{~N}-\mathrm{HCl}$ and diluted to $5 \mathrm{ml}$. with water containing 1500 p.p.m. strontium to suppress phosphate interference. The atomic absorption of the solution was measured and read against a standard curve for $\mathrm{Ca}^{2+}$ prepared at the same time. Values lay within the range of 0.2-1.2 p.p.m. calcium. Duplicates were within 10\%, as were different batches of the organism. The same solution, sometimes with further dilution, could be used for $\mathrm{Mg}^{2+}$ analyses within the range of $0 \cdot 1-1 \cdot 5$ p.p.m.

\section{RESULTS}

\section{Composition of cell walls}

Removal of the poly- $\beta$-hydroxy-butyric acid by extraction with chloroform enabled us to obtain satisfactorily clean preparations of cell walls, free from high refractive index material as judged by phase and electron microscopy. Walls prepared in this way contained the ' $R$ ' layer components (Weidel, Frank \& Martin, 1960)glucosamine, muramic acid, glutamic acid, alanine and diaminopimelic acid, as well as the usual wide range of amino acids found in Gram-negative walls; in this case, lysine, aspartic acid, glycine, serine, valine, methionine, leucine and tryptophane were present, together with glucose and rhamnose.

\section{Cell-wall composition in relation to calcium nutrition}

The peculiarly swollen appearance of cells of Rhizobium trifolii (Vincent \& Colburn, 1961) led us to believe that the shape-determining rigidity of the cell wall had been lost. The ' $R$ ' layer components were, however, found to be qualitatively alike, whether the organism had been grown in the presence or absence of $\mathrm{Ca}^{2+}$, and all the other amino acids and sugars were also present in the calcium-deprived walls. It seemed therefore that the deficiency might lie in the $\mathrm{Ca}^{2+}$ itself, or in the organization of the components.

\section{Calcium and magnesium analyses of whole cells and cell walls}

Table 1 summarizes the results of $\mathrm{Ca}^{2+}$ and $\mathrm{Mg}^{2+}$ analyses of cells and cell walls. Those grown in the presence of calcium were thereafter deprived of $\mathrm{Ca}^{2+}$ by ethylene diamine tetra-acetic acid (freeze-dried normal material was exposed to M/10 EDTA in $\mathrm{M} / 200$ tris buffer, value $\mathrm{pH} 7 \cdot 0$, at $0^{\circ}$ overnight); those grown in the absence of calcium were then exposed to $\mathrm{Ca}^{2+}$ (freshly harvested deprived cells were exposed either to normal medium containing $0.5 \mathrm{~mm}-\mathrm{Ca}^{2+}$ for $1 \mathrm{hr}$. at $25^{\circ}$ or to $10 \mathrm{~mm}-\mathrm{CaCl}_{2}$ in $\mathrm{M} / 100$ tris buffer, value $\mathrm{pH} 8$, at $0^{\circ}$ for $72 \mathrm{hr}$.). In each case, where organisms were exposed to $\mathrm{Ca}^{2+}$, they were washed five times with water, and a cell-wall preparation was then made. 
The following conclusions could be drawn: (1) In 'normal' organisms the $\mathrm{Ca}^{2+}$ concn. in the cell wall was $25 \%$ greater than that in the cell as a whole. (2) The total $\mathrm{Ca}^{2+}$ in deprived cells was very low (about $10 \%$ of normal) and this was probably almost all accounted for by the amount retained in the walls (approximately $60 \%$ of the normal wall $\mathrm{Ca}^{2+}$ content). (3) The deficiency of $\mathrm{Ca}^{2+}$ in the whole cell was compensated by additional $\mathrm{Mg}^{2+}$. This did not apply to the walls. Those of deprived cells still had less than $75 \%$ of the total divalent cations of normal walls. (4) EDTA removed most of the cations, $\mathrm{Mg}^{2+}$ as well as $\mathrm{Ca}^{2+}$, from normal whole cells and walls. The small part resistant to removal would seem to be more strongly bound in the structure of the cell and wall. (5) Exposure of the deprived cells and walls to $\mathrm{Ca}^{2+}$ (in normal medium and as dilute $\mathrm{CaCl}_{2}$ ) led to its uptake, more strikingly in the whole cells than in the walls. The concentration of $\mathrm{Ca}^{2+}$ in the walls remained appreciably below the value of walls of cells grown in the presence of $\mathrm{Ca}^{2+}$.

Table 1. Calcium and magnesium content of cells grown in the presence and absence of calcium

$+=$ normal cells grown in $0.5 \mathrm{mM}-\mathrm{Ca}^{2+}+0.5 \mathrm{mM}-\mathrm{Mg}^{2+},-=$ calcium deprived cells grown in $1 \mathrm{~mm}-\mathrm{Mg}^{2+}$.

\begin{tabular}{|c|c|c|c|c|}
\hline \multirow[b]{2}{*}{ Fraction } & \multirow{2}{*}{$\begin{array}{c}\text { Calcium status and } \\
\text { treatment }\end{array}$} & \multicolumn{3}{|c|}{$\mathrm{mm} / \mathrm{g}$. dry wt. of cells } \\
\hline & & Calcium & Magnesium & Total \\
\hline Whole cells & \pm & $\begin{array}{l}0 \cdot 062 \\
0.007\end{array}$ & $\begin{array}{l}0 \cdot 064 \\
0 \cdot 154\end{array}$ & $\begin{array}{l}0 \cdot 126 \\
0 \cdot 161\end{array}$ \\
\hline Cell walls & $\begin{array}{l}+ \\
-\end{array}$ & $\begin{array}{l}0.081 \\
0.047\end{array}$ & $\begin{array}{l}0.016 \\
0.024\end{array}$ & $\begin{array}{l}0.097 \\
0.071\end{array}$ \\
\hline Whole cells & $\stackrel{+}{+} \underset{\text { EDTA treated* }}{*}$ & $0 \cdot 008$ & 0.005 & 0.013 \\
\hline Cell walls & $\stackrel{+}{+}$ EDTA treated & $0 \cdot 010$ & 0.005 & 0.015 \\
\hline Whole cells & $\left.\begin{array}{c}- \\
\text { Exposed } 1 \text { hr.* } \\
\text { to normal medium }\end{array}\right\}$ & $0 \cdot 019$ & - & - \\
\hline Cell walls & $\left.\begin{array}{l}\text { Exposed } 1 \mathrm{hr} . \\
\text { to normal medium }\end{array}\right\}$ & 0.054 & - & - \\
\hline Whole cells & $\left.\begin{array}{c}\overline{-} \\
\text { Exposed } \overline{72} \mathrm{hr}^{*} \\
\text { to } \mathrm{M} / 100 \mathrm{CaCl}_{2}\end{array}\right\}$ & $0 \cdot 058$ & - & - \\
\hline Cell walls & $\begin{array}{l}\text { Exposed } \overline{72} \mathrm{hr} \\
\text { to } \mathrm{M} / 100 \mathrm{CaCl}_{2}\end{array}$ & $0 \cdot 063$ & - & - \\
\hline
\end{tabular}

Observations by phase and electron microscopy of the EDTA-treated organisms did not reveal the striking morphological abnormalities seen in cells deprived of $\mathrm{Ca}^{2+}$ during their growth. The electron micrographs of cells shadowed with platinum did, however, indicate some loss of structure in that those treated with EDTA had lost their smooth contours and had the walls wrinkled and collapsed in an angular manner over the cytoplasm. Phase observations of deprived cells exposed to $\mathrm{Ca}^{2+}$ failed to reveal any convincing evidence of morphological recovery. 


\section{DISCUSSION}

Calcium deprivation could affect the cell wall in various ways:

(1) Calcium may have a catalytic role in the manufacture of the rigid-layer components. However, in the case of rhizobium, the walls of cells grown in the absence of added $\mathrm{Ca}^{2+}$ had the same ' $\mathrm{R}$ ' layer components, amino acids and sugars, as those grown in its presence. It seems therefore that dependence of ' $R$ ' layer precursors on $\mathrm{Ca}^{2+}$ is not the explanation of the observed condition.

(2) Calcium may be needed for organizing the ' $R$ ' layer or other components into a rigid unit. Primosigh, Pelzer, Maass \& Weidel (1961) pointed out that the peptide side chains of the ' $R$ ' layer which contain diaminopimelic acid would carry an excess negative charge which would need to be neutralized before they could be packed into a tight, rigid structure. It is feasible to visualize the specificity of $\mathrm{Ca}^{2+}$ being associated with its having, unlike $\mathrm{Mg}^{2+}$, the dimensions that permit it to fit structurally into such a network. Recent growth observations by one of us (J.M.V.) have shown that $\mathrm{Sr}^{2+}$, but not $\mathrm{Ba}^{2+}$, could replace $\mathrm{Ca}^{2+}$, though less efficiently, to support the growth of cells of normal morphology. If the dimension of the ion is involved, this observation fits with the respective place of $\mathrm{Mg}, \mathrm{Ca}, \mathrm{Sr}$ and $\mathrm{Ba}$ in the group of alkaline earths. There is some evidence that $\mathrm{Ca}^{2+}$ may be involved structurally in bacterial cell walls, apart from that presented in this paper. Keerer \& Gray (1960) found up to $70 \%$ of radioactive $\mathrm{Ca}^{2+}$ incorporated into the cell-wall fraction of Listeria monocytogenes. Murti (1960) prepared spheroplasts of Vibrio cholerae and Escherichia coli by suspending the cells in EDTA with lysozyme. Lysozyme attacked the polysaccharide backbone of the ' $R$ ' layer (Salton \& Ghuysen, 1960) and the function of the EDTA could be to withdraw $\mathrm{Ca}^{2+}$ from the structure.

(3) Calcium may affect the stability and permeability of proteins present in the wall. Takahashi \& Gibbons (1959) found that $\mathrm{Ca}^{2+}$ and $\mathrm{Mg}^{2+}$ protected the cells of Micrococcus halodenitrificans from swelling under unfavourable salt concentrations. Nermut (1960) found that Proteus large bodies became permeable to Alcian blue after treatment with lauryl sulphate and EDTA, suggesting that removal of $\mathrm{Ca}^{2+}$ has altered the permeability of the cell membrane. Brown (1961) found that the ionic strength of the medium, and particularly the concentration of divalent cations, determined the amount of cell envelope protein formed in a marine pseudomonad. Organisms growing on media of low ionic strength contained low concentrations of cell-wall protein and became spherical. Levy \& Slobodiansky (1950) suggested that under conditions of unfavourable ionic strength the amount of protein synthesized in a system was reduced since proper hydrogen bonding did not occur, and the entropy of the system was too high for synthesis to continue. In rhizobium the effect of $\mathrm{Ca}^{2+}$ and $\mathrm{Sr}^{2+}$ was more specific since the swollen cells were seen in the presence of excess $\mathrm{Mg}^{2+}$, sufficient to keep the total molarity of divalent cation constant. It is possible, however, that here the $\mathrm{Ca}^{2+}$ was specifically involved in stabilizing cell wall protein and that in the absence of $\mathrm{Ca}^{2+}$, this wall protein was present in reduced quantity.

We were not able to simulate the morphological appearance of calcium-deprived cells by treatment of normal cells with EDTA, nor to restore normal morphology by exposure of deprived cells to $\mathrm{Ca}^{2+}$. These observations, combined with the difficulty in restoring normal $\mathrm{Ca}^{2+}$ content to walls of deprived cells, compared with the 
relative ease with which the whole cell took up the ion, suggested that there was an active incorporation of $\mathrm{Ca}^{2+}$ into the wall during growth, and that this was what was required for normal morphology. Alternatively, the $\mathrm{Ca}^{2+}$ could have been required to assist the normal formation of wall protein during cell growth. Cells grown in insufficient $\mathrm{Ca}^{2+}$ could not then be restored to normal by later addition of $\mathrm{Ca}^{2+}$, nor would the removal of $\mathrm{Ca}^{2+}$ at that stage have any effect on a wall already synthesized. Noller \& Hartsell (1961) studied the effect of pre- and co-lytic treatment of Escherichia coli and Aerobacter with lysozyme. They suggested that the action of EDTA and other agents (butanol, heat) in potentiating the action of lysozyme was by dissociation of the lipoprotein rather than the ' $R$ ' layer component of the wall. It is possible that in rhizobium also, $\mathrm{Ca}^{2+}$ may be concerned as much with the stability of the lipoprotein as with that of the ' $R$ ' layer portion of the wall.

The help and guidance of Dr B. G. Davey, Soil Science Laboratory of the School of Agriculture, in connexion with the atomic absorption technique is gratefully acknowledged. Our thanks are also due to Dr Drummond and Mr Shorey, Electron Microscope Unit, University of Sydney. The work reported in this paper was supported by the Commonwealth Reserve Bank (Rural Credits Division), the Wheat Industry Research Funds and the Research Committee, University of Sydney.

\section{REFERENCES}

Brown, A. D. (1961). Effects of salt concentration during growth on properties of the cell envelope of a marine pseudomonad. Biochem. biophys. Acta, 49, 585.

KeERER, R. F. \& Gray, M. L. (1960). Antigenic and related biochemical properties of Listeria monocytogenes. J. Bact. 80, 683.

Levy, M. \& Slobodiansky, E. (1950). The application of the isotopic derivative technique to the study of protein structure. Cold Spr. Harb. Symp. quant. Biol. 14, 113.

Murti, K. (1960). Preparation of bacterial enzymes by controlled lysis. Biochim. biophys. Acta, 45, 243.

Nermut, M. V. (1960). Cytological observations of protoplasts and large bodies of bacteria. I. The surface membrane. Folia Biologica Prague, 6, 239.

Noller, E. G. \& Hartsell, S. E. (1961). Bacteriolysis of Enterobacteriaceae. II. Preand co-lytic treatment potentiating the action of lysozyme. J. Bact. 81, 482.

Primosigh, J., Pelzer, A., Maass, D. \& Weidel, W. (1961). Chemical characterization of mucopeptides released from the Escherichia coli wall by enzymic action. Biochim. biophys. Acta, 46, 68.

Salton, M. R. J. \& Ghuysen, J. M. (1960). Acetyl-hexosamine components enzymatically released from Micrococcus lysodeikticus. Biochim. biophys. Acta, 45, 335.

Takahashi, I. \& Grbbons, N. E. (1959). Effect of salt concentration on the morphology and chemical composition of Micrococcus halodenitrificans. Canad. J. Microbiol. 5, 25.

VinCENT, J. M. (1962). Influence of calcium and magnesium on the growth of rhizobium. J. gen. Microbiol. (in the Press).

Vincent, J. M. \& Colburn, J. R. (1961). Cytological abnormalities in Rhizobium trifolii due to a deficiency of calcium and magnesium. Aust. J. Sci. 23, 269.

Vincent, J. M., Humphrey, B. \& North, R. J. (1962). Some features of the fine structure and chemical composition of Rhizobium trifolii. J. gen. Microbiol. 29, 551.

Weidel, W., Frank, H. \& Martin, H. M. (1960). The rigid layer of the cell wall of Escherichia coli strain B. J. gen. Microbiol. 22, 158. 